\title{
VARIATIONS IN POPULATION SIZES OF FIVE RODENT TAXA ACROSS A HABITAT GRADIENT IN THE SINHARAJA RAINFOREST, SRI LANKA
}

\author{
Mayuri R. Wijesinghe
}

Department of Zoology, University of Cambridge, Cambridge, CB2 3EJ, United Kingdom (Corresponding address) Department of Zoology, University of Colombo, Colombo 3, Sri Lanka

Email: mrw@webmail.cmb.ac.lk

\begin{abstract}
This paper investigates population fluctuations of five rodent taxa across a habitat gradient in areas within and adjacent to the Sinharaja rainforest in Sri Lanka. Live trapping was conducted monthly during a continuous period of 13 months in 1998 and 1999. Four habitat types, ranging from undisturbed forest to habitats subject to varying levels of human disturbance were selected. The five taxa investigated were Srilankamys ohiensis, Rattus rattus kelaarti, R. r. kandianus, Mus mayori and M. booduga. Srilankamys ohiensis and Mus mayori are endemic species. The populations of these rodents were relatively stable, with fluctuations being of small magnitude. The densities were low, with the densities of rat species fluctuating between 0-5/ha and the densities of mouse species ranging from 0-10/ha during most of the survey period. Population sizes generally synchronized with rainfall patterns, being higher during the wetter season when fruits were abundant. Recapture rates of all taxa were quite low and this was seen to be the case in all of the four habitat types sampled. Differences were evident in the distribution patterns of the taxa, the most striking observation being the restriction or the predominance of the endemic species in the forest habitats. Monthly habitat usage patterns further indicated that none of the taxa exhibited seasonal migration between the different habitat types, implying that the populations of these rodents were largely insular.
\end{abstract}

KEYWORDS

Densities, disturbance, endemics, habitat usage, mice, Mus booduga, M. mayori, rats, Rattus rattus kandianus, $R$. $r$. kelaarti, Sinharaja, Sri Lanka, Srilankamys ohiensis

Communities are dynamic entities. Within them, populations of species undergo fluctuations in abundance over time, often displaying regular population cycles (Halama \& Dueser, 1994). The structure and dynamics of small mammal populations in general reflects variations in the demographic attributes of the individuals in that population as they interact with the biotic and abiotic factors of the environment (Happold \& Happold, 1991; Skupski, 1995). Consequently, one would expect habitat characteristics to have an effect on population dynamics of small mammals and this has been demonstrated in many studies (August, 1983; Zollner \& Lima, 1997). In the tropics, with continuing deforestation, many natural habitats are drastically altered giving rise to patches of natural forest that are often surrounded by agricultural land or human settlements. This paper investigates the variability of population densities of five rodent taxa across habitats subject to varying levels of human disturbance, in the Sinharaja rainforest in Sri Lanka. The Sinharaja forest is located in the wet zone of Sri Lanka, between $6^{0} 21^{\prime}-6^{0} 26^{\prime} \mathrm{N} \& 80^{\circ} 21^{\prime}-80^{\circ} 34^{\prime} \mathrm{E}$. The vegetation of the northwestern section of the rainforest, where this study was conducted, is classified as lowland wet evergreen forest. The forest was designated a Biosphere Reserve under UNESCO's Global Network of Biosphere Reserves. Subsequently, UNESCO declared it as a Natural World Heritage. The five rodent taxa investigated are the endemic species Srilankamys ohiensis and Mus mayori, a non-endemic species Mus booduga and two subspecies of the non-endemic species Ratus rattus, namely, $R . r$. kandianus and $R . r$. kelaarti.

\section{Methodology}

Data from a 13-month trapping regime was used to compare the population densities of the five selected murids in different habitat types in Sinharaja. Four major habitat types were selected, namely, unlogged forest, consisting of pristine closed forest with a relatively dense canopy and trees of large height and girth; forest that had been selectively logged in the 1970s (called logged forest); border areas of the forest that had earlier been cleared, cultivated with cash crops and subsequently abandoned for several years and now in secondary scrub jungle (called abandoned habitats) and border areas that were cleared and is used for raising permanent plantations of pine, rubber, tea or cinnamon, and now having monocrops of these species (called plantation).

Eight sampling plots, two in each of the four habitats, were live trapped monthly for a period of 13 months during 1998 and 1999. The unlogged and logged plots were sampled from March 1998 to March 1999, while the abandoned and plantation plots were sampled from June 1998 to June of the following year. In each site a trapping grid of $40 \times 90 \mathrm{~m}$ was set up and sampling was conducted on four consecutive days each month. All animals were identified, toe-clipped, sexed, weighed, measured and released at the sites of capture. The recorded data was used to examine seasonal variations in the population sizes of the taxa, in the different habitats, over the sampling duration of 13 months.

Population size was estimated using the "minimum number known alive (MNKA)" method introduced by Krebs (1966), and monthly population density, expressed as the minimum

(C) Zoo Outreach Organisation; www.zoosprint.org Manuscript 1374; Received 06 June 2005; Finally accepted 19 November 2005; Date of publication 21 December 2005 January 2006 | ISSN 0973-2535 (Print edition); 0973-2551 (Online edition) 
number of animals per hectare, was calculated for each grid. Densities of each species were calculated by dividing the MNKA values by the effective trapping area of the grid. The latter was taken to be the total sampling area of the grid plus a boundary strip equal to the average distance individuals of a species moved between successive captures (Flowerdew, 1976; Gurnell \& Gipps, 1989). The daily rainfall and temperature data at the research station, Sinharaja, were recorded by the Department of Botany, University of Peradeniya. The research station is situated within the study site.

\section{Results}

\section{Climatic conditions in Sinharaja during the study period}

Fig. 1 shows the total monthly rainfall and average monthly temperature in Sinharaja during the period of the present survey. The annual rainfall of the forest during 1998 and 1999 exceeded $4000 \mathrm{~mm}$. Generally, precipitation is high from April to December, the southwest monsoon bringing rain from May to July and the northeast monsoon from October to December, while in the remaining months rains occur due to convectional and low pressure systems. There is a predictable relatively dry season from January to March, although the rainfall in these months also exceeded $150 \mathrm{~mm}$ in 1998 and 1999. Climate in the forest remains relatively warm throughout the year, with the daily temperature fluctuations being greater during the drier months.

\section{Trends in population density}

The monthly densities of the five rodent taxa are shown in Fig. 2. With the majority of the taxa monthly captures were few and intermittent, many sessions yielding zero captures in one or both grids within a particular habitat type. Recapture rates (i.e. the number of individuals that were captured in two or more trapping sessions during the 13-month survey) of all species were low in all of the four habitat types sampled. Rattus rattus kandianus had the highest recapture rates recording mean values of $25.2 \%$ in unlogged, $38.9 \%$ in logged, $29.9 \%$ in abandoned and $25.4 \%$ in plantation habitats. Both Srilankamys ohiensis and R. r. kelaarti had similar recapture rates, 28.2\% and $26.7 \%$ in unlogged and $21.7 \%$ and $22.5 \%$ in logged habitats. From among the two mouse species, Mus mayori had higher recapture rates than $M$. booduga, recording $35 \%$ in unlogged,

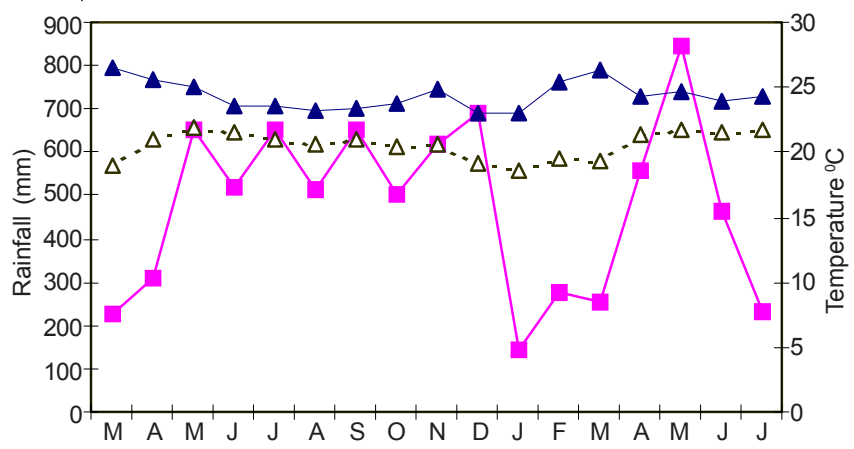

Figure 1. Monthly rainfall and average monthly temperature values for Sinharaja in the period March 1998 to July 1999. (Rainfall - squares, max. temp. - blocked triangles and min. temp. - open triangles)
$33.7 \%$ in logged, $36.6 \%$ in abandoned and $15 \%$ in plantation habitats. M. booduga had recapture rates of $23.5 \%$ in abandoned and $18 \%$ in plantation habitats. Furthermore, monthly habitat usage patterns indicated that none of the species exhibited seasonal migration between the different habitat types, implying that the populations of these species were largely insular. Three taxa, S. ohiensis, $R$. $r$. kelaarti and $M$. booduga characteristically utilized one or two habitat types throughout the year, while the other two taxa, $R$. $r$. kandianus and $M$. mayori, were seen to consistently utilize the four habitats all year round, though the latter was much more abundant in forest habitats.

The five murids exhibited monthly variations in densities, although none of the taxa showed strong seasonal trends. The rat populations appeared to be relatively stable with densities varying between 0-5/ha (Fig.2). The highest densities were recorded for $R$. r. kandianus. Its densities attained a peak of 5/ ha in abandoned habitats, but during most of the year populations fluctuated from $2-4 /$ ha. These numbers were more or less similar in all four habitat types and the seasonal patterns exhibited were also consistent across the habitats. The densities of $S$. ohiensis and $R$. r. kelaarti were slightly lower, generally varying from $0-3 /$ ha over the months of the survey. These two taxa were absent from non-forest habitats, with the exception of a single individual of $R$. r. kelaarti captured from an abandoned plot. With S. ohiensis, the seasonal trends observed were different in the unlogged and logged sites. The unlogged sites maintained higher densities during the rainy season declining slightly towards the beginning of the relatively dry season, in January. In the logged sites, however, very few individuals were captured during the first few months of the survey, but densities were seen to reach levels observed in the unlogged sites after August. The densities of $R$. r. kelaarti were greater in the unlogged sites than in the logged sites during most months. Its densities were high during June to November and generally low between February and May.

With regard to the mice, the densities of Mus mayori far exceeded that of its congener M. booduga and its seasonal trends were also more pronounced (Fig. 2). In forest habitats, the densities usually varied from 4-10/ha but reached a peak of 14/ha in logged forests in April 1998. Densities in both forest habitats then dropped gradually and the lowest densities were recorded during the relatively dry season between January and March. The densities in non-forest sites were considerably lower than in forest habitats. M. booduga (found only in the non-forest sites) occurred at lower densities (0-4/ha), recording zero captures in some months leading to the haphazard fluctuation patterns observed. Densities in both non-forest habitats were however comparable, with the numbers being generally higher during the months of September and October.

The Two-way ANOVA was used to test for significant betweenhabitat variations in population densities of each species over the months of the survey and the results are presented in Table 1. The analyses were restricted to the months June 1998 to March 1999. It is evident from the results that the densities of 
Srilankamys ohiensis

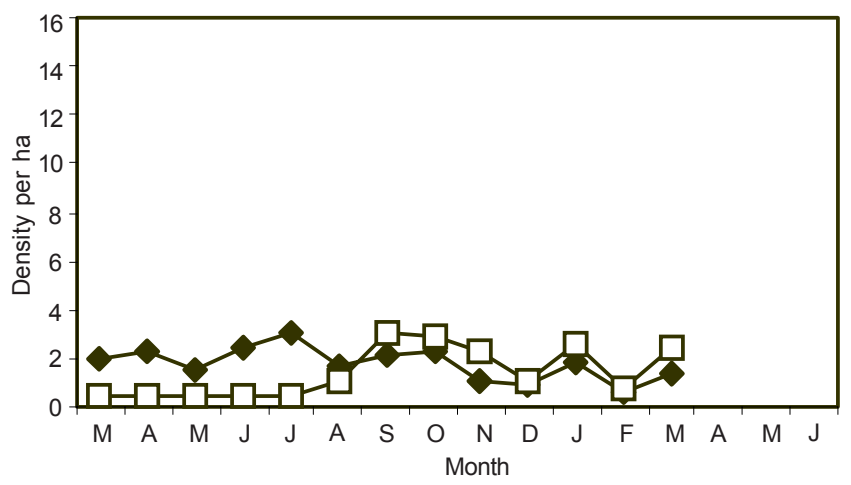

Rattus rattus kelaarti

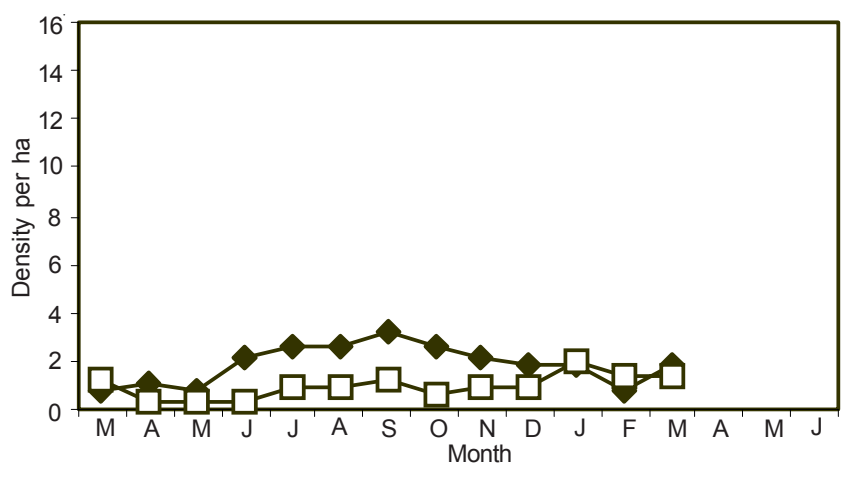

Mus booduga

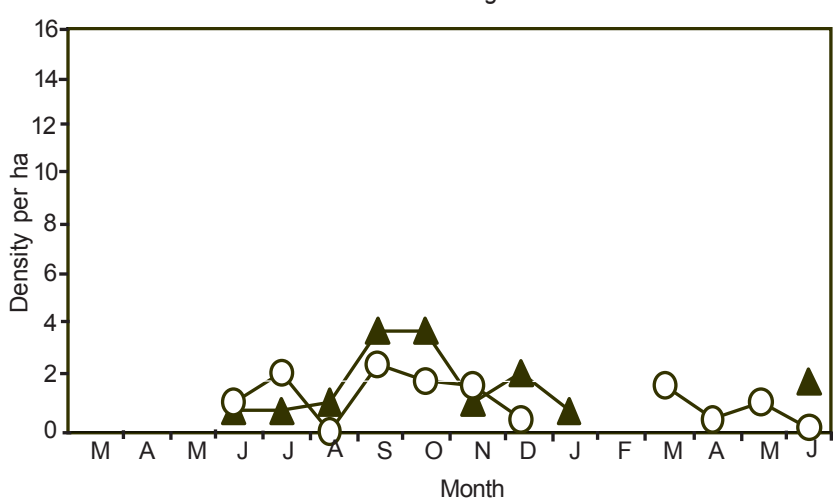

S. ohiensis, R. r. kelaarti, M. mayori and M. booduga varied significantly between habitats with the first three taxa being significantly more abundant in forest habitats and the last mentioned restricted to non-forest habitats. In contrast, $R . r$. kandianus did not exhibit significant differences in densities across the four habitats. The density fluctuations over the months per se were not significant for $S$. ohiensis, $R$. r. kelaarti and $M$. mayori but varied significantly in $R$. r. kandianus and M. booduga.

Although density fluctuations of the taxa were low to moderate, seasonal trends were identifiable. Populations were seen to increase with the onset of the rains during the two months April and May and relatively large populations were maintained over the next few months until September/October, after which
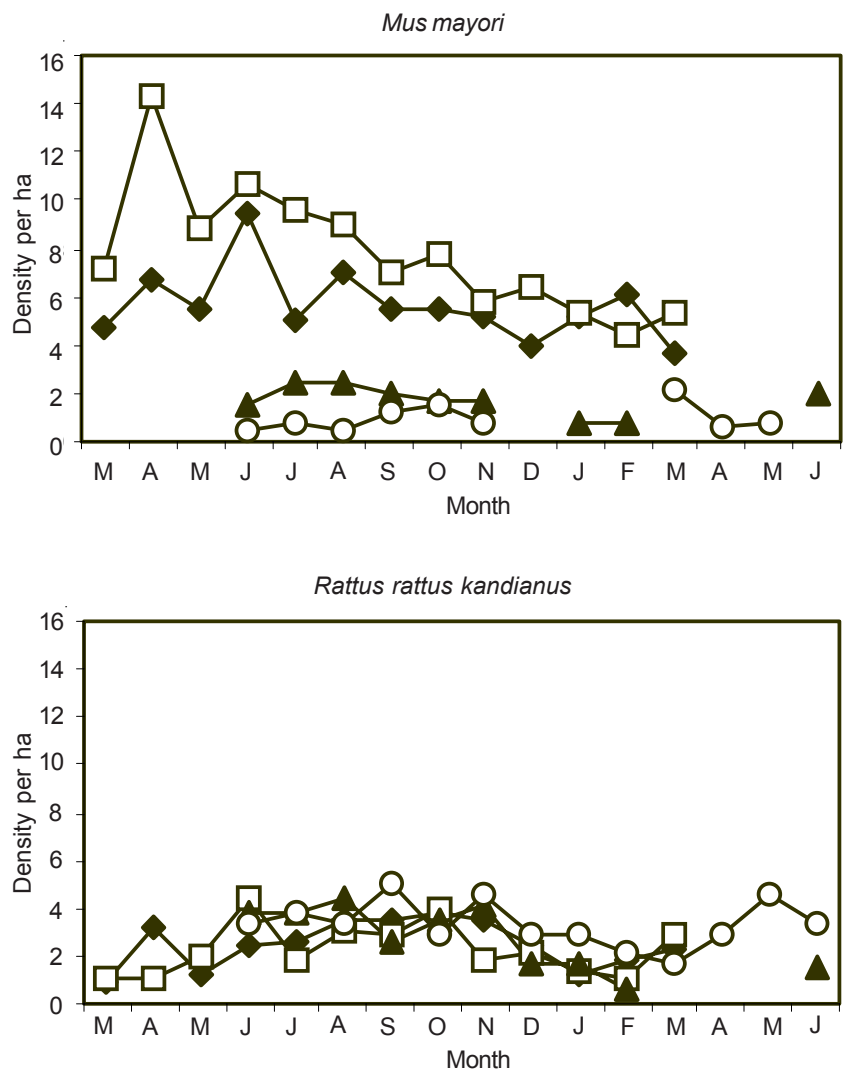

Figure 2. Seasonal fluctuations in the mean densities of the five species of murids Srilankamys ohiensis, Rattus rattus kelaarti, R. r. kandianus, Mus mayori and $\mathrm{M}$. booduga, over a 13-month trapping session in the four habitat types within and around the Sinharaja forest. (The unlogged and logged sites were sampled from March to March whilst the abandoned and plantation sites were sampled from June to June, during 1998 and 1999 and the two plots were sampled in each habitat type. The habitat types are indicated by: unlogged - blocked diamonds, logged - open squares, abandoned - open circles and plantation - blocked triangles).

densities declined. The lowest densities of most taxa were recorded between November and March. Therefore, monthly density fluctuations were synchronized with the rainfall patterns observed within the Sinharaja forest. The interaction effect, habitat by month, was not significant for any of the species indicating that none of the species exhibited differences in habitat occupancy patterns over the sampling duration.

\section{Discussion}

Investigations in tropical forests involving the trapping of small mammals are subject to several constraints. One of the problems arises from the low densities; in attempting to maximize both the number of species and the number of captures in such lowdensity habitats, sampling has to extend over relatively large areas making the procedure very cumbersome and time 
Table 1. Summary of Two-way ANOVA results for density fluctuations of the five species of murids, with plots $(n=8$, i.e. two plots within each habitat type) as the units of observation

\begin{tabular}{|c|c|c|c|c|c|}
\hline $\begin{array}{l}\text { Source of } \\
\text { variation }\end{array}$ & $\begin{array}{l}\text { Sum of } \\
\text { squares }\end{array}$ & d.f. & $\begin{array}{l}\text { Mean } \\
\text { square }\end{array}$ & $F$ & $P$ \\
\hline \multicolumn{6}{|c|}{ Srilankamys ohiensis } \\
\hline Habitat & 60.839 & 3 & 20.28 & 33.72 & $0.001^{* *}$ \\
\hline Month & 7.086 & 9 & 0.78 & 1.31 & 0.263 \\
\hline Habitat-by-month & 22.452 & 27 & 0.83 & 1.38 & 0.173 \\
\hline Error & 24.055 & 40 & 0.60 & & \\
\hline \multicolumn{6}{|c|}{ Rattus rattus kelaarti } \\
\hline Habitat & 62.437 & 3 & 20.81 & 82.68 & $0.001^{* * *}$ \\
\hline Month & 2.124 & 9 & 0.23 & 0.94 & 0.504 \\
\hline Habitat-by-month & 9.611 & 27 & 0.35 & 1.41 & 0.157 \\
\hline Error & 10.068 & 40 & 0.25 & & \\
\hline \multicolumn{6}{|c|}{ Rattus rattus kandianus } \\
\hline Habitat & 6.51 & 3 & 2.17 & 1.40 & 0.255 \\
\hline Month & 58.04 & 9 & 6.45 & 4.18 & $0.001^{* * *}$ \\
\hline Habitat-by-month & 39.56 & 27 & 1.47 & 0.95 & 0.550 \\
\hline Error & 61.77 & 40 & 1.54 & & \\
\hline \multicolumn{6}{|l|}{ Mus mayori } \\
\hline Habitat & 612.61 & 3 & 204.2 & 35.20 & $0.001^{* * *}$ \\
\hline Month & 71.66 & 9 & 7.96 & 1.37 & 0.233 \\
\hline Habitat-by-month & 88.97 & 27 & 3.30 & 0.57 & 0.937 \\
\hline Error & 232.07 & 40 & 5.80 & & \\
\hline \multicolumn{6}{|l|}{ Mus booduga } \\
\hline Habitat & 39.374 & 3 & 13.125 & 13.92 & $0.001^{* * *}$ \\
\hline Month & 19.638 & 9 & 2.182 & 2.31 & $0.034^{*}$ \\
\hline Habitat-by-month & 35.429 & 27 & 1.312 & 1.39 & 0.168 \\
\hline Error & 37.728 & 40 & 0.943 & & \\
\hline
\end{tabular}

${ }^{*} \mathrm{P}<0.05 ;{ }^{* *} \mathrm{P}<0.01 ;{ }^{* *} \mathrm{P}<0.001$

consuming, and most often leading to less accurate data in terms of individuals in well defined areas (Mares \& Ernest, 1995). Another drawback is that trappability of animals in rainforests is greatly affected by weather conditions which influence capture rates on different days as well as in different seasons. For instance, on wet nights the animals tend to be more stationary, making the capture of those individuals less likely. In addition, on wet days, there is lower dispersal of the aroma of the bait, resulting in reduced effectiveness. Despite the inherent drawbacks, this survey has generated sufficient information to enable comparison of the population densities of the study taxa across the four habitat types.

The densities of murids recorded in this study are comparable to results from other studies in tropical forests based on similar live trapping protocols. In the present investigation, the rat populations appeared to be relatively stable with densities varying from $0-5 /$ ha, while the densities of the mouse species varied from $0-14 /$ ha. In Uganda, densities of all species of rodents were in the range of 0.7 and $21.3 /$ ha in mature evergreen forest and 0.7 to 26/ha in selectively felled forests (IsabiryeBasuta \& Kasenene, 1987). Jeffery (1977) reported an average density of 15.6 /ha in Ghana.

The occurrence patterns of the taxa (with the exception of $R$. $r$. kandianus) showed that more than $90 \%$ of the individuals occurred in one or two habitat types. The endemics (S. ohiensis and $M$. mayori) and $R$. r. kelaarti were entirely confined to, or were much more abundant in, forest areas, clearly indicating their preference for natural forest. It must be noted that selective logging took place almost three decades ago prior to the investigation and these areas have remained undisturbed since then. The non-endemic M. booduga on the other hand, was found only in non-forest habitats. Only R. $r$. kandianus did not exhibit a clear preference for specific habitat types, and was equally abundant in forest and non-forest sites. This is not surprising because Rattus rattus is a ubiquitous species with an ability to colonize readily and breed successfully in agricultural and secondary habitats as well as in undisturbed primary habitats. The consistent patterns of occupancy throughout the survey indicate that none of the species exhibited seasonal migration.

Although the population densities of murids in the present study did not show the pronounced seasonal trends that are typical of rodents in temperate climates (Montgomery, 1980), it was clear that the taxa did exhibit changes in densities throughout the year. Moreover, the seasonal trends observed were broadly similar among the taxa, although the fluctuations were of dissimilar magnitude. The population densities of $S$. ohiensis, R. r. kelaarti, R. r. kandianus and M. mayori were higher during the months April to July, gradually decreasing towards the latter part of the year. The lowest densities were usually recorded at the beginning of the year between January to March when drier weather conditions prevailed. Peaks in the breeding season in most habitats were seen to occur primarily during the drier months, although the presence of a few reproductively active individuals at other times suggests that breeding may occur intermittently throughout the year. The elevated monthly densities during the wetter months were due to new individuals being recruited into the population. Although Sri Lanka's wet zone has been described as a seasonal (Ashton \& Gunatilleke, 1987), the forests have distinct periods of flowering and fruiting. Phenological observations carried out by the author in Sinharaja have shown that the peak fruiting season in the forest is during the months March to August, when rainfall is heavy. Increased populations occur at this time when food is thus most abundant. Hence, as suggested by Madsen and Shine (1999), and Shanker and Sukumar (1999), the murid populations in this study appear to be climaticallydriven indicating that population fluctuations are linked to food availability in the rainforest.

\section{Conclusion}

Habitat type appears to have a profound effect on the distribution and population dynamics of the small mammal taxa inhabiting sites within and around the Sinharaja forest. All taxa in general had low population densities, and seasonal fluctuations were of low magnitude highlighting the stability of tropical rodent populations. Trends were nevertheless evident during the year for most species. The trends were possibly climatically-driven, with breeding and recruitment closely following rainfall regimes and hence probably linked to food availability in the forest. It is noteworthy that the two endemic murids appear to be forest specialists, suggesting that the disturbance of the natural rainforests will have a deleterious 
effect on the populations of these small mammal species.

\section{REFERENCES}

August, P.V. (1983). The role of habitat complexity and heterogeneity in structuring tropical mammal communities. Ecology 64: 1495-1507. Ashton, P.A. and C.V.S. Gunatilleke (1987). New light on plant geography of Ceylon I. Historical plant geography. Journal of Biogeography 14: 249-285.

Flowerdew, J.R. (1976). Ecological methods. Mammalian Review 6: 123-159.

Gurnell, J. and J.H.W. Gipps (1989). Inter-trap movement and estimating rodent densities. Journal of Zoology, London 217: 241-254. Halama, K.J. and R.D. Dueser (1994). Of mice and habitats: Tests for density-dependent habitat selection. Oikos 69: 107-114.

Happold, D.C.D. and M. Happold (1991). An ecological study of small rodents in the thicket-clump savanna of Lengwe National Park, Malawi. Journal of Zoology, London 223: 527-547.

Isabirye-Basuta, G. and J.M. Kasenene (1987). Small rodent populations in selectively felled and mature tracts of Kibale forest, Uganda. Biotropica 19: 260-266.

Jeffery, S.M. (1977). Rodent ecology and land use in western Ghana. Journal of Applied Ecology 14: 741-755.

Krebs, C.J. (1966). Demographic changes in fluctuating populations of Microtus californicus. Ecological Monographs 36: 239-273.

Madsen, T. and R. Shine (1999). Rainfall and rats: Climatically-driven dynamics of a tropical rodent population. Australian Journal of Ecology 24: 80-89.

Mares, M.A. and K.A. Ernest (1995). Population and community ecology of small mammals in gallery forests of Central Brazil. Journal of Mammology 76: 750-768.

Montgomery, W.I. (1980). Population structure and dynamics of sympatric Apodemus species (Rodentia: Muridae). Journal of Zoology, London 192: 351-377.

Shanker, K. and R. Sukumar (1999). Community structure and demography of small mammal populations in insular montane forests in southern India. Oecologia 116: 243-251.

Skupski, M.P. (1995). Population ecology of the Western Harvest Mouse, Reithrodontomys megalotis: A long-term perspective. Journal of Mammalogy 76: 358-367.

Zollner, P.A. and S.L. Lima (1997). Landscape-level perceptual abilities of the white-footed mice: Perceptual range and the detection of forested habitat. Oikos 80: 51-60.

\section{ACKnowledgement}

I am very grateful to the Cambridge Commowealth Trust and the National Science Foundation of Sri Lanka for supporting this work. I also wish to thank the Forest Department, Sri Lanka, for granting permission to carry out this study in the Sinharaja forest.

\section{LACERATED WOUND IN AN INDIAN PANGOLIN MANIS CRASSICAUDATA}

\author{
I. Nath ${ }^{1}$, V.S.C. Bose ${ }^{1}$, S.K. Panda ${ }^{2}$, \\ R.K. Samantray ${ }^{3}$ and P.K. Roy ${ }^{3}$
}

\begin{abstract}
${ }^{1}$ Department of Surgery, ${ }^{2}$ Department of Pathology, Orissa Veterinary College, Bhubaneswar, Orissa 751003 , India

${ }^{3}$ Veterinary Officer, Nandankanan Zoo, Orissa, India
\end{abstract}

web supplement

The Indian Pangolin (Manis crassicaudata) has a wide distribution range in India. Little is known about infectious diseases of pangolins (Kuehn, 1986). The present paper describes management of a lacerated wound in an Indian Pangolin of Nandankanan Zoo.

An animal keeper of the nocturnal house at Nandankanan Zoo observed a wound on the ventral aspect of the abdomen of a pangolin during routine inspection. The animal was shifted to the isolation ward for treatment. The Pangolin was restrained by grasping the tail and hanging it upside down, a method normally practised to control this animal. On examination a lacerated wound measuring $10 \times 2 \mathrm{~cm}$ extending from xiphoid area to anterior aspect of umbilicus was found (Image $1^{\mathrm{w}}$ ). The wound was irrigated with luke warm potassium permanganate lotion and dried with clean absorbent cotton swab. Povidine-iodine (Betadine 5\%) ointment was applied to the wound and the dressing continued, intramuscular injection of cefotaxime sodium $250 \mathrm{mg}$ bid (twice a day) was also administered for five days. The wound healed within a month and the pangolin was released to its enclosure. After two days there was recurrence of the wound. On examination small pebbles were found inside the wound. The previous treatment was again continued keeping the Pangolin in the isolation ward. As there were pebbles sticking to the wound, the nocturnal house was inspected. A hole was found in one corner of the concrete floor along with blood stains. As Pangolins are powerful burrowers the wound might have been caused due to the sharp concrete pieces removed while burrowing. Dressing and parenteral antibiotic administration resulted in healing of the wound. Immediate repair of the concrete floor prevented recurrence of the wound. The present article emphasizes the importance of maintaining proper husbandry techniques to prevent such conditions.

\section{REFERENCES}

Kuehn, G. (1986). Pholidota, pp.618-619. In: Fowler, M.E. (Ed.). Zoo and Wild Animal Medicine. $2^{\text {nd }}$ edition. W.B. Saunders Company, Philadelphia.

\section{ACKNOWLedgement}

Authors are thankful to M. Mohapatra, Assistant Director, Nandankanan Zoo for his cooperation and advice.

${ }^{\mathrm{w}}$ see Image 1 in the web supplement at www.zoosprint.org

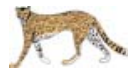

(c) Zoo Outreach Organisation; www.zoosprint.org Manuscript 1366; Received 24 May 2005; Finally accepted 10 July 2005; Date of publication 21 December 2005 